\title{
Perceptions of patients with rheumatic diseases on the impact on daily life and satisfaction with their medications: RHEU-LIFE, a survey to patients treated with subcutaneous biological products [Corrigendum]
}

González CM, Carmona L, de Toro J, et al. Patient Prefer Adherence. 2017;11:1243-1252.

On page 1245, Results; Response rate and sample description section, the second sentence "The mean age of the respondents was 41.7 years (SD 13.1), and $57.6 \%$ of them were females" should read "The mean age of the respondents was 51.7 years (SD 13.1), and $57.6 \%$ of them were females".

\section{Publish your work in this journal}

Patient Preference and Adherence is an international, peer-reviewed, open access journal that focusing on the growing importance of patient preference and adherence throughout the therapeutic continuum. Patient satisfaction, acceptability, quality of life, compliance, persistence and their role in developing new therapeutic modalities and compounds to optimize clinical outcomes for existing disease states are major areas of interest for the journal. This journal has been accepted for indexing on PubMed Central. The manuscript management system is completely online and includes a very quick and fair peer-review system, which is all easy to use. Visit http:// www.dovepress.com/testimonials.php to read real quotes from published authors. 